\title{
Slavery Discourse in Brazil: the case of Banco do Brasil (1885-1902)
}

\section{Discurso Escravagista no Brasil: o caso Banco do Brasil (1885-1902)}

\section{Discurso Esclavista en Brasil: el caso del Banco do Brasil (1885-1902)}

\begin{abstract}
Objective: The article aims to study the slavery discourse in Brazil at the end of the 19th century through the financial statements and annual reports of Banco do Brasil between 1885 and 1902.

Method and approach: Specifically, we carry out a critical analysis of the discourse of Banco do Brasil's financial statements and annual reports between 1885 and 1902 using concepts from Karl Marx's political theory: reification, commoditization and dehumanization.

Main results: We argue that the ideology practiced in relation to the slave shows the superstructure necessary for the structure. We suggest that the discourse employed reified the slave, considering it as a thing, commoditizing the slave, including its exchange value, as an asset, as a guarantee, depriving it of all forms of human dignity (dehumanization).
\end{abstract}

Contributions: By studying accounting with a critical purpose, we can contribute to other uses of our discipline, such the employed discourse and its dialectics in accounting practice. Therefore, the discourse is justified and makes slavery part of the national ruling class's conception of the world, which must permeate throughout society.

Originality/relevance: This paper contributes to the understanding of how accounting, including its discourse and concepts can be used by the ruling class to justify racism and slavery in Brazil.

Keywords: Slavery. Accounting. Banco do Brasil. Critical Discourse. 


\section{RESUMO}

Objetivo: $\mathrm{O}$ artigo tem como objetivo estudar o discurso da escravidão no Brasil do final do século XIX por meio das demonstrações financeiras e relatórios anuais do Banco do Brasil entre 1885 e 1902.

Método e abordagem: Especificamente, realizar uma análise crítica do discurso das demonstrações financeiras e relatórios anuais do Banco do Brasil entre 1885 e 1902 a partir de conceitos da teoria política de Karl Marx: reificação, comoditização e desumanização.

Principais resultados: Argumentamos que a ideologia praticada em relação ao escravizado mostra a superestrutura necessária à estrutura. Sugerimos que o discurso empregado reifica o escravizado, considerando-o como uma coisa; mercantilizar o escravizado, inclusive seu valor de troca, como bem, como garantia, privando-o de toda forma de dignidade humana (desumanização).

Contribuições: Ao estudar contabilidade com finalidade crítica, podemos contribuir para outros usos de nossa disciplina, como o discurso empregado e sua dialética na prática contábil. Nesse sentido, o discurso se justifica e faz da escravidão parte da concepção de mundo da classe dominante nacional, que deve permear toda a sociedade.

Originalidade e relevância: Contribui para a compreensão de como a contabilidade, incluindo seu discurso e conceitos, pode ser utilizada pela classe dominante para justificar o racismo e a escravidão no Brasil.

Palavras-chave: Escravidão. Contabilidade. Banco do Brasil. Discurso crítico.

\section{RESUMEN}

Objetivo: El artículo tiene como objetivo estudiar el discurso de la esclavitud en Brasil a fines del siglo XIX a través de los estados financieros y los informes anuales del Banco do Brasil entre 1885 y 1902.

Método y enfoque: Específicamente, realizar un análisis crítico del discurso de los estados financieros e informes anuales del Banco do Brasil entre 1885 y 1902 a partir de conceptos de la teoría política de Karl Marx: cosificación, mercantilización y deshumanización.

Principales resultados: Argumentamos que la ideología practicada en relación al esclavizado muestra la superestructura necesaria para la estructura. Sugerimos que el discurso empleado cosifica al esclavizado, considerándolo como una cosa; comercializar al esclavizado, incluido su valor de cambio, como un bien, como garantía, privándolo de toda forma de dignidad humana (deshumanización).

Prosppectus - Perspectivas Qualitativas em Contabilidade e Organizações. João Pessoa. v. 1, n. 1, p. 1 - 18, jul/2021. 
Contribuciones: Al estudiar la contabilidad con un propósito crítico, podemos contribuir para otros usos de nuestra disciplina, como el discurso utilizado y su dialéctica en la práctica contable. En este sentido, el discurso se justifica y hace de la esclavitud parte de la cosmovisión de la clase dominante nacional, que debe permear a toda la sociedad.

Originalidad y relevancia: Contribuye a la comprensión de cómo la clase gobernante puede utilizar la contabilidad, incluidos su discurso y conceptos, para justificar el racismo y la esclavitud en Brasil.

Palabras clave: Esclavitud. Contabilidad. Banco do Brasil. Discurso crítico.

\section{INTRODUCTION}

Brazil was one of the last countries in the world to officially abolish slavery in 1888 through the Golden Law (Lei Áurea). However, this process has been going on for some decades, mainly due to foreign pressure, national abolitionist movements and the resistance of slaves. In this sense, several laws were previously enacted, such as the Eusébio de Queiróz Law in 1850, which abolished the slave trade; Ventre Livre Law (1871), which granted freedom to the children of slaves and Sexagenários Law (1885), freeing slaves over 60 years of age (Prado Jr., 2012).

Although the end (?) of the atrocities was commendable, slaves were left to their own devices. There were no inclusive policies for this population, so they were marginalized from the economic dynamics and socially reduced. The effects are still perceived today, through the structural racism of Brazilian society: blacks are those who most die in a violent way or suffer police violence, most impacted by unemployment and helplessness, most suffer from the failures of educational and housing systems and national health, etc.

Many researches in accounting have studied the issue of slavery and / or its abolition in several dimensions. In one of them, he considers the culpability of accounting and its practitioners in the practice of slavery (Oldroyd, Fleischman \& Tyson, 2008).

Another view is the use of accounting reflecting the commoditization, objectification, and dehumanization of the slave class in a Marxist approach (Fleischman \& Tyson, 2004; Hollister \& Schultz, 2010). Several studies have observed and analyzed accounting practices in relation to slave transactions and their institutionalization (Pinto \& West, 2017; Craig \& Rodrigues, 2018; Oldroyd, Fleischman \& Tyson, 2011; Tyson \& Oldroyd, 2019; Silva, 2014; Baker, 2019).

As stated by Marx (2013, p. 820) when discussing slavery and its conditions: “(...) transformation of Africa into a reserve for the commercial hunting of black skins that Prosppectus - Perspectivas Qualitativas em Contabilidade e Organizações. João Pessoa. v. 1, n. 1, p. 1 - 18, jul/2021. 
characterize the dawn of the era of capitalist production. These idyllic processes constitute moments fundamentals of primitive accumulation." . This reflects its dialethic cause-consequence in the human existence (Marx, 2008):

\footnotetext{
In the social production of existence itself, men enter into relationships determined, necessary, independent of your will; these relationships of production correspond to a certain degree of development of their material productive forces. The totality of these relations of production constitutes the economic structure of society, the real basis on which a legal and political superstructure to which particular social forms of consciousness correspond. The mode of production of material life conditions the process of social, political and intellectual life (p. 47).
}

The objective is to elucidate how the accounting discourse seeks to reinforce social relations based on race, transforming the slave and its use as merchandise, with exchange value and reflected in monetary terms to the detriment of the entire human dimension of dignity.

Specifically, we will analyze with a Marxist-critical approach the discourse contained in the financial statements and annual reports of Banco do Brasil, an important and secular Brazilian financial institution, present in the country since 1808 in relation to slavery, under aspects of commoditization, objetification and dehumanization. For that, we used primary data in the period between 1885 and 1902, which contains the year of abolition (1888).

As a contribution, we realized in our analysis in line with Fleischman and Tyson (2004) and Hollister and Schltz (2010) that accounting and its practice, including in the discourse used, reinforce the racist construction of society to commoditization, objectification, and dehumanization of the black people.

Our paper is structured as follows. After this introduction, we discussed the main theoretical aspects, elucidating a short history of slavery in Brazil, as well as the history and importance of Banco do Brasil, in addition to discussing articles that study slavery with a Marxist-critical perspective. Next, we show aspects of the method, present the results, conclusions and final considerations.

\section{THEORETICAL DISCUSSION}

\subsection{Aspects of slavery in Brazil}

The eighteenth-century world carries with it great changes, especially those in charge of England, such as the Hargreaves spinning machine, the James Watt steam engine, etc. Capital was more than necessary: the incipient bourgeoisie gave rise to new markets. However, recent capitalism led to war, as verified between the powers England 
and France. The continental blockade that had the task of taking the Portuguese royal family and the court to Brazil is an example of this dispute. (Alencar, Carpi \& Ribeiro, 1994)

In the 19th century, with the arrival of Portuguese absolutists, life in the colony and its customs changed dramatically. An immense variety of organs are created that previously existed only in the metropolis: "for many, bureaucratic gigantism was a way of justifying the presence of so many pointed or whitewashed sailors in the colony. (Alencar, Carpi \& Ribeiro, 1994). After all, it was necessary to give functions to all members of the Court and their aggregates. One of these institutions was Banco do Brasil in 1808 .

In addition to the large and traditional farmers in the northeast of the country's former wealth, sugar, the petty bourgeoisie was born mainly in the Court and then in São Paulo: the large, small and medium-sized producers of the new national wealth and the entire industry linked to their needs, the coffee. These were the national elite in the 19th century, added to the court itself.

Viotti da Costa (2010) provides an overview of the Brazilian elite that "takes power in 1822", composed of farmers, traders and their clientele, closely linked to the dynamics of import / export, interested, above all "in the maintenance of traditional production structures whose foundations were the slave labor system and large property." (p. 11). In the author's view, there is the purging of liberal thoughts and the endowment of an anti-democratic, elitist spirit, including the subordination of the Church to the State.

But in the formation of the Brazilian elite in the 19th century, Viotti da Costa (2010) affirms that it distanced itself or "adopted an ambiguous position in relation to bourgeois ethics and capitalism", since it excelled in the "cult of individual freedom, in the valorization work and savings ", a fact that "did not make much sense in a society where work was done by slaves, human relations were defined in terms of exchange of favors and social mobilization depended on the patronage of the elite." (p. 13).

The most important issue was slave labor.

In addition to the free Brazilians outside the coffee aristocracy, a large mass was totally excluded and subjected to the most perverse punishments that one person can do to another (note the necessarily capitalist economic aspect of this relationship): the slaves. This thesis does not fit here to discuss the psychological and social aspects of the act of enslaving a person: I will focus on its infinitely smaller dimension, however infinitely greater in the treatment by scholars, the economic dimension of the official cessation of slavery activities in our territory.

Prosppectus - Perspectivas Qualitativas em Contabilidade e Organizações. João Pessoa. v. 1, n. 1, p. 1 - 18, jul/2021. 
We corroborate the view of Florestan Fernandes (1972) that black people, both captive and freedmen were foreign bodies to Brazilian society in the 19th century: it was "as if they were inside the city walls, but did not collectively participate in their economic life, social and political." (p. 82)

The whole question of ending slavery, from trafficking, births, sexagenarians and ending with complete abolition, is a curious fact in our economic history since many affirm the great development that the country went through with the end of this social injustice and human. It allowed the creation of private institutions illusory, resulting from the accumulation of capital once employed in the trafficking of people from Africa. It also creates a more classic capitalist relationship when you start to pay, the famous wage labor.

This dimension of human activity grows a lot in Brazil, most notably after 1880, a fact that characterizes much of what we created as a concept of work in our current society. Caio Prado Jr. (2012) highlights in many passages of the Economic History a certain shame and dismay of members of our official administration regarding the issue of abolition, a fact that corroborates the thesis of no interest at the end of it, since it went against his economic yearnings. The development and subsequent breakdown of banking and credit institutions in the country are explained by the speculative capitals once employed in the slave trade.

Slavery did not only degrade blacks, but the entire nation: the question of blacks was not new, since Brazil was forced since the beginning of the 19th century, most notably by England in the abolition of slavery. The expansion of coffee itself raised the issue, since more labor was needed. Of two one: or more slaves or free arms. In 1822, the year of independence, according to Alencar, Carpi and Ribeiro (1994), half of our population was composed of slaves, "and in 1850 that number reached the mark of 2.5 million people." (p. 169). As Furtado (2007) points out:

More than in any other matter, it is difficult to separate exclusively economic aspects from others of a broader social character. Constituting slavery in Brazil the basis of a secularly established life system, and characterizing the slave economic system by a great structural stability, it is easily explained that for the man who integrated this system the abolition of servile labor assumed the proportions of a "social hecatomb". Even the most lucid and fundamentally anti-slavery spirits, such as Mauá, never came to understand the real nature of the problem and were filled with fright in the face of this inevitable "hecatomb". The idea then prevailed that a slave was a "wealth" and that the abolition of slavery would result in the impoverishment of the sector of the population that was responsible for the creation of wealth in the country. (p. 199).

Prosppectus - Perspectivas Qualitativas em Contabilidade e Organizações. João Pessoa. v. 1, n. 1, p. 1 - 18, jul/2021. 
A first point to be touched must be made with respect to the question of labor, since the free Brazilian population, both those from urban areas and those from subsistence agriculture, had difficulty regarding adaptation to living conditions. on the farm in relation to the discipline that agricultural work required: Furtado (2007) teaches that this fact contributed to forming the opinion that the country's free labor force was not suitable for large crops." (p. 176): the alternative solution was to develop European immigration. However, the same author points out that "there was no precedent on the continent for European immigration of free labor to work on large plantations." (p. 181).

Alencar, Carpi and Ribeiro (1994) point out that Brazil and England lived in a climate of war: the Empire had to give in, even with resistance from the farmers, issuing several emancipatory regulations before the abolition itself, such as the Eusébio de Queirós Law of 1850, which prohibited trafficking; the Free Belly Act of 1871, freeing the born and the Sexagenarian Law of 1885, freeing the elderly slaves. The emperor himself identified himself with the abolitionist cause since the 50s.

Thus, the suspension of trafficking while relieving the diplomatic issue, additionally creating an internal market, which could benefit both producers in the North (who would sell their slaves) and those in the Center-South, who would buy them. However, as raised by Prado Jr., the pre-law Áurea regulations, such as the Lei do Ventre Livre, resulted in Prado Jr.'s (2012) vision in a "last analysis, if not a diversion, a maneuver in great style that blocked a lot more than favored the evolution of the slave problem in Brazil." (p. 179). The author estimates that in this direction slavery would take 50 to 60 years to disappear in the country!

But at the same time, the issue of immigration took shape again, with the intensification of landings on national lands: only in São Paulo did the number of immigrants rise from 13,000 immediately after the 50 s to 184,000 in the 80 s and in the last decade of the century to 609 thousand. (Furtado, 2007).

In the 80 s, the slave and monarchic climates were worn out, losing support in all corners of society. On May 13, 1888, Princess Isabel signed the Golden Law. For Alencar, Carpi and Ribeiro (1994), this meant the legal freedom of blacks, but not of life, as they were thrown in the dark and without any form of integration into society, contributing little "to end the idea of the inferiority of blacks (...) further aggravated the marginalization of black populations." (p. 207). Racial prejudice has been reinforced in an important way.

In this event, Viotti da Costa (2010) analyzes that the progress of the Brazilian economy in the second half of the century led to a profound imbalance between economic power and political power: that 1822 system seemed inappropriate in the $80 \mathrm{~s}$, since the new urban elites did not feel sufficiently represented and farmers in coffee 
areas, producers of much of the country's wealth, "felt plagued by the political structures of the Empire." (p. 17).

\subsection{Brief history and importance of Banco do Brasil in the 19th century}

The first foundation of Banco do Brasil was set up in 1808, formed by a capital of 1,200 contos de réis, divided into 1,200 shares with a par value of 1 short story each. According to this document, the institution's operations consisted, then, of the commercial discount on bills of exchange drawn or accepted by credit dealers, national or foreign; in the commission of computations collected from individuals or public establishments, or in advance through mortgages; in the general deposit in silver, gold, diamonds or cash; issuing bills or bills payable to the bearer, at least 30 thousand réis; in the commission of private withdrawals or the Real Erário, of funds located abroad or national, in a remote area; on receipt of the entire sum, offered to him under the law; in the commission for the sale of private types of contracts and royal administration, such as diamonds, brazilwood, ivory and urzela; in the trade of gold and silver species. Even so, however, one of its tasks, not clarified in its statutes, during those first years of existence was the provision of capital to cover the expenses of the huge court brought to the country, a fact that led to the bank's closure in 1833, due the large number of withdrawals made by members linked to the Court. (Cardoso, 2010). The institution in that first period had been used as a means of financing only one class, the nobility.

The second birth of Banco do Brasil dates 1851, promoted by Barão de Mauá, who two years later merged the institution with Banco Comercial do Rio de Janeiro, considered the first operation of this type in the banking industry in the country. It started operations two years later, in 1853. (BB, 2010).

One should not confuse the Banco do Brasil by Irineu Evangelista (private) with that which emerged in 1851 ("public"). From the merger of these two private banks, Banco do Brasil was born, "public or mixed", since although controlled by private entities in the Empire era, it had great influence, through the appointment of the institution's president and vice president, as well as definitions and interference with its operational policies.

We realized that since this new birth of Banco do Brasil, it was born with its pillars formed by private ideology, given that it is the product of the union of two private banks (Banco do Brasil de Mauá, which was not the public and Banco Commercial, from the city of Rio de Janeiro, also not public). In fact, the administrative machinery itself in those early years came from the two merged institutions.

With this background, the help of the Imperial Government is also notorious through the rapid provision of printed letters for Banco do Brasil with respect to its Prosppectus - Perspectivas Qualitativas em Contabilidade e Organizações. João Pessoa. v. 1, n. 1, p. 1 - 18, jul/2021. 
activities, according to Pacheco (1973). In fact "I am happy to be able to declare to you ... that in this and as in all other cases in which the Board had to address the imperial government, it always found it helpful to assist and protect it." (p. 159).

However, the most serious shock occurred with the end of slavery in the 80s, which caused the loss of many guarantees, since the bank had numerous operations guaranteed by the recently abolished, in addition to the difficulties brought about by the increase in production, having to look for free arms and, consequently, wage earners to perform the activities formerly performed by the freedmen. (BB, 2010).

In this vein, the government once again provides funding for the institution and the Treasury in order to intensify loans to our deficient crops: this fact is accentuated in the last months of the Empire, with the rise of the Viscount of Ouro Preto to the Fazenda portfolio, including the founding of a real credit bank - Banco Nacional do Brasil - of great scope and also supported by government guarantees. (BB, 2010).

Even with the proclamation of the Republic on November 15, 1889, Banco do Brasil and the Ministry of Finance, in those early years, through Rui Barbosa, its minister, continued to work hard with the intention of saving agriculture, our main wealth. (BB, 2010).

\subsection{Previous studies about slavery and accounting}

Some studies address the issue of accounting and the practice of slavery.

One view points out that accounting is seen as morally unfair in supporting slavery for its alienation of the right to individual property, but also as a tool for emancipation, in trying to preserve life and even more, the value of stocks (Oldroyd, Fleischman \& Tyson, 2008).

Accounting with an emancipatory purpose through the transformation of governance and accountability structures. Social accounting intertwined the representation of alienation with resistance, allowing subordinates capable of promoting structural changes in the conditions to which they were subjected. (Alawattage \& Wickramasinghe, 2009).

The evolution of emancipatory accounting itself initiates paths that allow a libertarian development within the capitalist system itself. (Gallhofer \& Haslam, 2019).

The use of terms from the dynamics of accounting in the slave trade is commonly cited when addressing what accounting does in commoditizing slaves, by transforming their characteristics into categories to facilitate their monetization (Fleischman \& Tyson, 2004).

Prosppectus - Perspectivas Qualitativas em Contabilidade e Organizações. João Pessoa. v. 1, n. 1, p. 1 - 18, jul/2021. 
Pinto and West (2017) point out that the accounting techniques that the Companhia Geral do Grão-Pará and Maranhão show guilt and preserve details of the dark circumstances of the existence of slavery.

\section{METHODOLOGICAL ISSUES}

In order to achieve the research objective, a historical study was conducted with primary data of a critical nature and with a qualitative approach, which uses the analysis of discourse based on the concepts of Karl Marx (1818 - 1883).

Critical research has some references that can be condensed into the following propositions: all thinking is fundamentally mediated by power relations; facts are never isolated from the domain of values or separated from some form of ideological inscription; the relationship between the concept and the object, between the signifier and the signified is never stable or fixed; language is central to the formation of subjectivity, whether consciously or unconsciously; certain groups are privileged in relation to others (Chua, 1986).

\subsection{Data collection}

The primary data were obtained personally from the Banco do Brasil Historical Museum, located at the Banco do Brasil Cultural Center in Rio de Janeiro at Rua Primeiro de Março, 66 - Rio de Janeiro (RJ) in March 2016.

The financial statements of the bank years of 1853 - 1900 were obtained, totaling 48 pieces, with 1,285 pages in total.

In addition, the annual reports were obtained in which there are explanations about the figures contained in the financial statements, as well as the explanation of other relevant matters, totaling 45 pieces, with approximately 5,000 pages of content.

All were digitized and analyzed with Atlas Ti software. All pages on which slavery is mentioned were separated for the analysis of the discourse employed.

\subsection{Data analysis technique}

The data were studied from the perspective of Critical Discourse Analysis, derived from the Frankfurt School.

The task of Critical Discourse Analysis is to consider the language related to the social structure, evaluate the discourse's function, its ideology in the production, maintenance and transformation of social power relations, demystify the dominant discourses and build a critical conscience (Chizzotti, 2010).

Prosppectus - Perspectivas Qualitativas em Contabilidade e Organizações. João Pessoa. v. 1, n. 1, p. 1 - 18, jul/2021. 
In our study, we used the concepts of commoditization, objectification (reification) and dehumanization from Karl Marx's political theory and from later scholars like Lukács.

Generally, commoditization is the transformation of goods and services, including goods and services not usually seen as such, into a commodity. That is, the transformation of social relations into commercial relations, of exchange or purchase and sale, described in 1848 in the Communist Manifesto of Marx and Engels. It should be noted that the term appears years later in 1977 by the League of Young Communists in the USA. It corresponds to the treatment as commodities of things that are not (Feenberg, 2014).

Objectification or reification, on the other hand, consists of transforming ideas into concrete things or even transforming people into objects, being a form of alienation from the capitalist system. This concept, although contained in the Hegelian work, appears mainly with Lukács (Feenberg, 2014).

Finally, dehumanization corresponds to the denial of the full humanity of others and the suffering that comes with this process. It would be the construction of something human as not human, or without due human dignity. It serves to justify genocide, slavery, attacks, etc (Feenberg, 2014).

We will notice in our analysis that there is an interrelation between these concepts when used in the slave production scheme, since black people are treated as commodity, reinforcing the point that slavery as an idea was made concrete, as a social economic base and all the dehumanization by denying them human dignity, building something human in non-human.

\section{RESULTS}

Brazil maintained its slavery as a legal system until 1888. The slave was considered as one of the factors of production, as a thing, as possession, as an animal. A possession from your master. In this section, we aim to verify the treatment given in discourse in relation to black people and their relationship with ideology that is often prejudiced in relation to this class, with effect even today.

In the years before the Áurea law, the Bank was very concerned with one of the main guarantees of its mortgage portfolio (BB, 1886, 1887):

\footnotetext{
Although it is difficult to estimate crop guarantees today, as a result of the depreciation therein, especially in relation to the slave arm (emphasis added), even so by the knowledge of each debtor and the state of prosperity greater or lesser than each, for reduction that will present the balances of each contract, is the opinion of the management that of the Rs. 24,062: 442 \$ 920 lent to the farm,
}

Prosppectus - Perspectivas Qualitativas em Contabilidade e Organizações. João Pessoa. v. 1, n. 1, p. 1 - 18, jul/2021. 
Rs. 16,089: 090 \$ 540 are in the hands of debtors who have the resources to resolve their principal and interest debts, if not within the strict term of their contracts, with the extension of one - two more years.

If the real guarantee of depreciation today is certain, it is no less certain that it can improve tomorrow, and when it comes to an institution that does not die, time is an element to be counted on (emphasis added). (1886, p. 20).

The reification of the slave can be seen in the extract above, considered first of all as a "slave arm", like a machine or a workhorse, leaving the whole dimension of human dignity out of context. It reflects the conception of the ruling class at the time, of the transformation of the slave into an asset.

We even noticed that the term "depreciation" is used to reinforce this reification, since it has a value that is depreciating due to the abolitionist debates in the 1880s.

The commoditization of the slave can be included in the analysis, since as mentioned in the stratum above "(...) the real guarantee is depreciated today, it is no less certain that it can improve tomorrow (...)". Like a property or other property of a fixed character, the slave is seen as a "real guarantee", including fluctuations in value due to market conditions.

Therefore, we conclude that the discourse has the effect of dehumanization of the slave, by removing all human aspects, in favor of the economic interest of the ruling class (monocultures latifundios) in reifying and commoditizing black people.

The economic relationship comes above dignity, creating the idea that the slave as a thing, with exchange value, thus justifying slavery.

Pursuant to Law No. 3270 of September 28, 1885, the Bank was dispatched in March 1886 to circulate to all hypothetical debtors recommending that they postpone the registration of their slaves and, until September 30, send original documents, or authentic certificates. (emphasis added) Very few of them fulfilled this precept in time, so that on January 12, 1887, a new circular was issued, and it was necessary in the course of the month of March, for the Bank to put lawyers from various locations into activity or to register or to verify the existence in the Collectories. By this means, the Administration was certain that all slaves had been registered, under the conditions of being so, although until this date it does not have all the enrollments or certificates, and is therefore deprived of presenting the relations of the slaves and their values, as you have always done. (1887, p. 17 and 18).

The reification and commoditization of the slave is again perceived here, since Law 3,270 of 1885 asks all debtors to register (own document) their slaves, sending such certificates to institutions that had slaves given as guarantees for credit operations, including their values.

Prosppectus - Perspectivas Qualitativas em Contabilidade e Organizações. João Pessoa. v. 1, n. 1, p. 1 - 18, jul/2021. 
Since 1884, the regular operations of the hypothecaria portfolio will cease and only for the purpose of guaranteeing operations of a different nature, some have been carried out. Without stopping at the analysis of the reasons, which determined this resolution, it is rigorous to affirm that, in the present state of affairs, the indispensable basis for such operations is lacking, the appreciation of the value of the property - enhanced by such disturbances that, will continue to constitute the general impoverishment of the most important and almost exclusive industry in Brazil. (emphasis added). Over all the elements of demoralisation, the absence of credit destroys the basis on which the plan for the reorganization of the crop would have to be based, and while it was necessary to revive the energies of the farmers, everything has contributed to slaughter them, abandoning them in the decline in that most people don't even think about reacting. This deplorable situation needs remedy; farming is and will in the future be Brazil's natural industry and the source of its wealth; it invigorates it, surrounds it with the elements that can produce its restoration must be a general commitment and Banco do Brazil must give its contingent to this meritorious enterprise. If your interests do not advise the maintenance of the regime you have adopted, in agreement with the imperial government, other means will have to maintain an institution without which we can lose hope that the agricultural wealth will be strengthened, rather we will be sure of its progressive decay. (emphasis added). (1887, p. 8).

The issue of the abolition of slaves is also a very curious point in the way it is told: at no time is it commented on the atrocities committed, or the injustices. (BB, 1888):

If we consider the delay of one to three installments in hypothetical contracts, usually after a year of coffee failure and when we enter in a year of abundance, although surrounded by other difficulties, caused by the act of abolition (emphasis added). (p. 16).

They are treated as inanimate factors of production, as commodities. We argue that the abolition caused difficulties, did not solve injustices.

In addition, it created a major problem for Banco do Brasil, which had in its hands no more than 19,650 mortgaged slaves, with a value of more than 12 thousand contos. (BB, 1888):

After the law of May 13, the Bank proceeded with different kidnappings, some at the request of debtors, others because it was informed that borrowers lacked resources to pay wages, and the freedmen withdrew. As a simple statistical information, I found it convenient to state in this report that, when the extinction of slavery was decreed, the Bank had 19,650 slaves hypothesized, representing, according to the table that gave effect to law no. 3270, of September 28, 1885, in an approximate value of RS. 12,000,000 \$000 (emphasis added). (p. 18)

And how to account that? (BB, 1888):

It is evident that the disappearance of this guarantee must, in some cases, cause damage to the Bank (emphasis added), although it is not possible to

Prosppectus - Perspectivas Qualitativas em Contabilidade e Organizações. João Pessoa. v. 1, n. 1, p. 1 - 18, jul/2021. 
assess to what amount such losses will rise. (p. 18). If they are released (and owned by the bank), the value is zero. Solution: launch the expense or renegotiate the guarantees with the debtors.

In the following year, it is evident (BB, 1889):

This year, the effects of the great social revolution ended by the law of 13 May 1888, which ended slavery in Brazil, will continue to act. The shock that affected the crop, the main factor of our wealth, and with it all the other interests of society, naturally in solidarity, has been reflected in our balance sheets making the amount "securities in liquidation (our emphasis) increase. (p. 5).

The interest of the leading group confused with the general: once again, the question of ending unjust and cruel relations with Africans and their descendants is treated as a shock, an anomaly, which needed drastic measures to restore "all other interests of society "and the" main factor of our wealth. " (BB, 1889):

However, as great remedies are required, great remedies are needed, so the promette season runs smoothly and the Imperial Government is convinced that the crop was entitled to major repairs, effected contracts with several banks and helped create others, so that they could lend at a long term and at a moderate interest rate to farmers who presented real or real guarantees. These measures could not fail to produce prompt effects. This is how many of the discouraged will have courage, and all of them seem to be full of confidence in the future, and it can be said that the land is already beginning to appreciate and within three or four years the effects of the law of 13 May will have disappeared like that of the stone rains that plague the crops from time to time. (emphasis added) (p. 19)

Now for the comparison of the end of slavery with a shower of stones (BB, 1889):

Even so, we must sign here (...) in which the disappearance of the slave arm rendered the land and the spent coffee worthless (emphasis added). (p. 20).

Even after a few years of abolition, the mention of social catastrophe is still present (BB, 1892, 1902):

Subsequently, since the law of May 13 th annulled the value of an important part of the guarantee, on which these contracts rested, the fear that its settlement would be difficult, slow and damaging seemed to be well founded. Fortunately, there were no such apprehensions, thanks to the vitality of the crop, which was based on the fertility of the soil, rather than on the value of the servile arm (emphasis added). (1892, p. 28). (...) The result, however, of this succinct balance of profits and losses, arising from the verified liquidation, demonstrates that the Bank has not benefited from the aid provided to the crop real advantages, which could induce it to accept new agreements with the Government; but that he only realized them in order to respond to the appeal made to his feelings of patriotism by the same Government, which then manifested itself committed to tackling the labor crisis, with which the crop was profiting (emphasis added). (1902, p. 27)

Prosppectus - Perspectivas Qualitativas em Contabilidade e Organizações. João Pessoa. v. 1, n. 1, p. 1 - 18, jul/2021. 
In this section we verify the treatment given in terms of discourse to the issue of slaves and their abolition.

Seen as merchandise, as things, the end of the respective regime in our country was seen as an aberration, with clear consequences for the holders of the structure, who would have their profits more and more decimated, with the abolition crisis, even compared, as we saw, "a rain of stones".

Those holders of the means of production, including slaves, saw their guarantees lost, saw their estimated production costs likely to increase with the need for wage labor, saw the country on the verge of a coffee overproduction, as put by Netto (2009), predicted the collapse of its wealth, confused with that of the country.

\section{CONCLUSIONS}

Our work had to analyze the slavery discourse in Brazil between 1885 to 1902, the time of abolition (1888). More precisely, carry out a critical analysis of the discourse of Banco do Brasil's financial statements and annual reports (main financial institution, public-private institution), using the concepts of the Marxist theory of dehumanization, commoditization and reification.

The ideology in relation to the slave was nothing more than the superstructure necessary for the current structure. in the formation of the Brazilian elite in the 19th century, Viotti da Costa (2010) states that it moved away from or "adopted an ambiguous position in relation to bourgeois ethics and capitalism", since it excelled in the "cult of individual freedom, in the valorization of the work and savings", a fact that "did not make much sense in a society where work was done by slaves, human relations were defined in terms of exchange of favors and social mobilization depended on the patronage of the elite." (p. 13).

We found that the speech used in the financial statements and annual reports reified the slave, considering it as a thing; commoditization the slave, including its exchange value, as an asset, as a guarantee, depriving it of all form of human dignity (dehumanization). Such discourse justifies and makes slavery part of the national ruling class's conception of the world, which must permeate the whole of society.

We corroborate the view of Florestan Fernandes (1972) that the black, both captive and manumitted were foreign bodies to Brazilian society in the 19th century: it was "as if they were inside the city walls, but did not participate collectively in its economic life, social and political." (p. 82)

Prosppectus - Perspectivas Qualitativas em Contabilidade e Organizações. João Pessoa. v. 1, n. 1, p. 1 - 18, jul/2021. 
Our research aims to contribute to the study of structural racism in Brazil and more specifically in the accounting field, as accounting and its discourse can be used to justify atrocities, such as slavery.

As limitations, we point out the study of a single case (Banco do Brasil) in a short period of time when compared to the entire slavery period in Brazil. We suggest as future studies, new sources of primary data and other time frames.

\section{REFERENCES}

Alawattage, C.\& Wickramasinghe, D. (2009). Weapons of the weak: Subalterns' emancipatory accounting in Ceylon Tea. Accounting, Auditing \& Accountability Journal. https://doi.org/10.1108/09513570910945660.

Alencar, F, Carpi L. \& Ribeiro M. (1994). História da Sociedade Brasileira. Rio de Janeiro: Ed. Ao Livro Técnico.

Banco do Brasil (2010), História do Banco do Brasil. Belo Horizonte: UFJF.

Banco do Brasil (1885). Relatório Anual do Exercício de 1885. Rio de Janeiro. Brasil. (1886). Relatório Anual do Exercício de 1886. Rio de Janeiro. Brasil. (1887). Relatório Anual do Exercício de 1887. Rio de Janeiro. Brasil. (1888). Relatório Anual do Exercício de 1888. Rio de Janeiro. Brasil. (1889). Relatório Anual do Exercício de 1889. Rio de Janeiro. Brasil. (1890). Relatório Anual do Exercício de 1890. Rio de Janeiro. Brasil. (1891). Relatório Anual do Exercício de 1891. Rio de Janeiro. Brasil. (1892). Relatório Anual do Exercício de 1892. Rio de Janeiro. Brasil. (1893). Relatório Anual do Exercício de 1893. Rio de Janeiro. Brasil. (1894). Relatório Anual do Exercício de 1894. Rio de Janeiro. Brasil. (1895). Relatório Anual do Exercício de 1895. Rio de Janeiro. Brasil. (1896). Relatório Anual do Exercício de 1896. Rio de Janeiro. Brasil. (1897). Relatório Anual do Exercício de 1897. Rio de Janeiro. Brasil. (1898). Relatório Anual do Exercício de 1898. Rio de Janeiro. Brasil. (1899). Relatório Anual do Exercício de 1899. Rio de Janeiro. Brasil. (1900). Relatório Anual do Exercício de 1900. Rio de Janeiro. Brasil. (1901). Relatório Anual do Exercício de 1901. Rio de Janeiro. Brasil. (1902). Relatório Anual do Exercício de 1902. Rio de Janeiro. Brasil.

Baker, C. R. (2019). What can Thomas Jefferson's accounting records tell us about plantation management, slavery, and Enlightenment philosophy in colonial America? Accounting History, 24(2), 236-252. https://doi.org/10.1177/1032373218772589.

Cardoso, J.L. (2010). A new contribution to the history of Banco do Brasil (1808 - 1829): chronicle of a foretold failure. Revista Brasileira de História, 30(59), 165 - 189.

Prosppectus - Perspectivas Qualitativas em Contabilidade e Organizações. João Pessoa. v. 1, n. 1, p. 1 - 18, jul/2021. 
Chizzotti, A. (2010). Pesquisa qualitativa em ciências humanas e sociais. 3. ed. Petrópolis: Vozes.

Chua, W. F. (1986). Radical developments in accounting thought. The Accounting Review, 61(4), 601-632. https://www.jstor.org/stable/247360.

Feenberg A. (2014). The philosophy of praxis: Marx, Lukács and the Frankfurt School. London: Verso.

Fernandes, F. (1972). O negro no mundo dos brancos. São Paulo: Difel

Fleischman R. K, Oldroyd D, Tyson T. N (2004). Monetising human life: slave valuations on US and British West Indian plantations. Accounting History, 9(2),35-62. doi:10.1177/103237320400900203

Fleischman, R K., Oldroyd, D \& Tyson, T. (2011). Plantation Accounting and Management Practices in the US and the British West Indies at the End of Their Slavery Eras. The Economic History Review, 64 (3), 765-797. 10.1111/j.14680289.2010.00548.x

Fleischman, R K.; Tyson, T N. (2004). Accounting in service to racism: monetizing slave property in the antebellum South. Critical Perspectives on Accounting, 15, 376-399. 10.1016/S1045-2354(03)00102-3

Furtado, C. (2007). Formação econômica do Brasil. 22a ed., São Paulo: Cia Editora Nacional.

Gallhofer, S.; Haslam, J. (2019). Some reflections on the construct of emancipatory accounting: Shifting meaning and the possibilities of a new pragmatism. Critical Perspectives on Accounting, [S. 1.], 1-19.

Hollister J, Schultz S.M. (2010). Slavery and emancipation in rural New York: Evidence from nineteenth-century accounting records. Accounting History. 15(3), 371-405. doi:10.1177/1032373210368843

Marx, K. (2008). O 18 Brumário de Luis Bonaparte. In: Engels, F. A revolução antes da revolução. São Paulo: Expressão Popular.

(2013). O Capital: crítica da economia política. Livro I - o processo de produção do capital. São Paulo: Boitempo.

Netto, A. D. (2009). O Problema do Café no Brasil. São Paulo: Ed. UNESP.

Oldroyd, D., Fleischman, R \& Tyson, T. (2008). The culpability of accounting practice in promoting slavery in the British Empire and antebellum United States. Critical Perspectives on Accounting, 19, 764-784. 10.1016/j.cpa.2006.11.005.

Pacheco, C. (1973). História do Banco do Brasil. São Paulo: Ed. Instituto de Economia da Associação Comercial.

Pinto, O. \& West, B. (2017). Accounting and the history of the everyday life of captains, sailors and common seamen in eighteenth-century Portuguese slave trading. Accounting History, 22. 10.1177/1032373217703756.

Prado Jr, C. (2012). História Econômica do Brasil. São Paulo: Ed. Brasiliense.

Prosppectus - Perspectivas Qualitativas em Contabilidade e Organizações. João Pessoa. v. 1, n. 1, p. 1 - 18, jul/2021. 
Rodrigues, L. L. \& Craig, R. (2018). The role of government accounting and taxation in the institutionalization of slavery in Brazil, Critical Perspectives On Accounting, 57(C), 21-38. 10.1016/j.cpa.2018.02.001

Silva, A. R. (2014). Slavery Service Accounting Practices in Brazil: A Bibliographic and Document Analysis. Revista Contabilidade \& Finanças, 25(spe), 346-354. 10.1590/1808-057x201411060

Tyson, T. N., \& Oldroyd, D. (2019). Accounting for slavery during the Enlightenment: Contradictions and interpretations. Accounting History, 24(2), 212-235. $10.1177 / 1032373218759971$

Viotti da Costa, E. (2010). Da Monarquia a República. São Paulo: Ed. UNESP.

\section{NOTAS}

Contribuição de Autoria

\begin{tabular}{|l|l|}
\hline Contribuição & \multicolumn{1}{|c|}{ Samir Sayed } \\
\hline 1. Definição do problema de pesquisa & $\mathrm{X}$ \\
\hline 2. Fundamentação Teórica/Revisão de Literatura & $\mathrm{X}$ \\
\hline 3. Definição dos procedimentos metodológicos & $\mathrm{X}$ \\
\hline 4. Coleta de dados & $\mathrm{X}$ \\
\hline 5. Análise e interpretação dos dados & $\mathrm{X}$ \\
\hline 6. Revisão crítica do artigo & $\mathrm{X}$ \\
\hline 7. Escrita do artigo & $\mathrm{X}$ \\
\hline 8. Outros (especificar) & \\
\hline
\end{tabular}

\section{Editores}

Editora Geral: Viviane da Costa Freitag

Editora Adjunta: Victoria Puntriano Zuniga de Melo

\section{Histórico}

Recebido em: 30/03/2021

Revisado por pares em: 13/05/2021

Reformulado e recomendado para publicação: 21/07/2021

Publicado em: 30/07/2021 